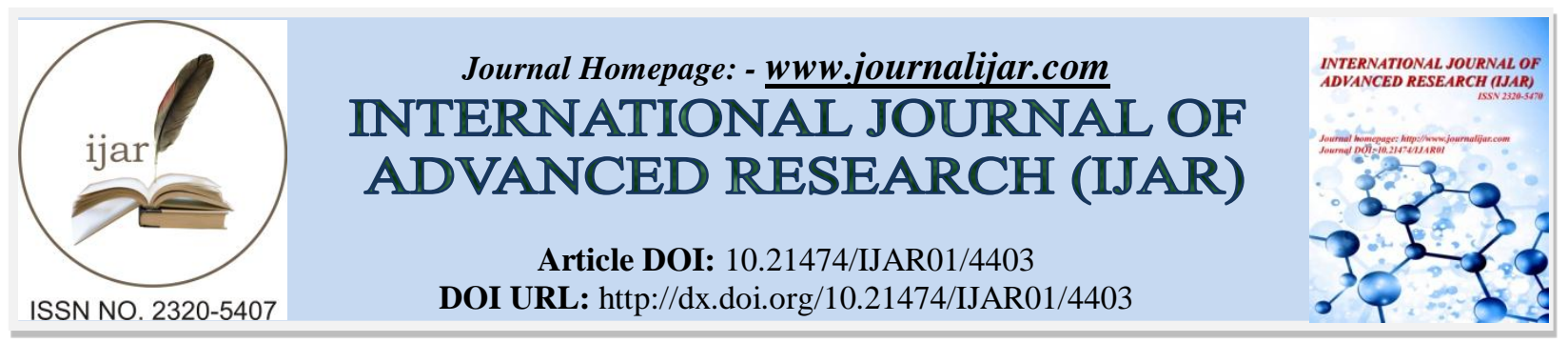

RESEARCH ARTICLE

\title{
AN INTRODUCTORY ETHNOBOTANICAL INVESTIGATION ON ZINGIBERALES USED BY MALAVETTUVAN AND MAVILAN TRIBE'S OF KASARAGOD DISTRICT, KERALA.
}

\author{
"V. P. Thomas, Judin Jose and Binoy T. Thomas.
}

Department of Botany, Catholicate College, Pathanamthitta, Kerala-689 645.

\section{Manuscript Info}

(...........................

Manuscript History

Received: 06 April 2017

Final Accepted: 07 May 2017

Published: June 2017

Key words:-

Ethnobotany, Zingiberales,

Malavettuvan, Mavilan, Kasaragod,

Kerala

\section{Abstract}

The present study was initiated to document indigenous knowledge on the utilization of ethanobotanically important plants of Zingiberales by Malavettuvan tribal's in Kasaragod District. During the present study a total of 11 ethanobotanically important plant species belonging to 5 families have been documented. These plants were used to treat various diseases, preparation of food, etc. The present study observed that, the Malavettuvan tribe of the Kasaragod District having very good knowledge on the traditional medicine. This type of studies may help pharmacological research in various dimensions.

Copy Right, IJAR, 2017,. All rights reserved.

\section{Introduction:-}

Etanobotany is the study of the relationship between plants and human beings. The focus of ethanobotany is on how plants have been or are used, managed and perceived in human societies and includes plants used for food, medicine, cosmetics, dyeing, textiles, for building, tools, currency, clothing, rituals, divination, social life and mucic (Chaudhary et al., 2008). Malavettuvan Tribe are distributed only in the Ghat areas of Kasaragod District and Kannur Districts of Kerala. They speak a dialet of Malayalam and Tulu (RSES, 2013). The Mavilan community is distributed in Kasaragod and Kannur District of Kerala. Mavilan community is experts in 'Punamkothu', which involves clearing of virgin forests and converting the same for wet land paddy cultivation (RSES, 2013).

The primary tropical Zingiberales include many conspicuous taxa, such as the bananas (Musaceae), birds of Paradise (Strelitziaceae), Heliconias (Heliconiacae) and Gingers (Zingiberaceae) (Kress et al., 2002). They are mainly distributed in tropics and subtropics with the centre of distribution in the Indo-Malayan region, but extending through tropical Africa to Central and South America (Kress et al., 2002; Tomlinson, 1969; Kong et al., 2010).

\section{Materials and Method:-}

\section{Study Area:-}

The Kasaragod district is the northernmost district of the State of Kerala. Kasaragod is located at $12.5^{\circ} \mathrm{N} 75.0^{\circ} \mathrm{E}$ and it has an average elevation of 19 metres. The ethanobotanical studies were conducted in various parts of Kasaragod district viz. Kozhichal, Thungal, Kallar, Kanhangad and Muttayam-Kochi (Map 1), during December 2016- January 2017.

\section{Collection of Ethnobotanical Information:-}

The data were collected by group discussions, direct interaction and personal interviews. The information obtained was documented in a data sheet. The data included the botanical name, local name, location, useful part, uses, mode of preparation, administration and their utility as remedy for treating diseases. 


\section{Ailment Categories:-}

Based on the information obtained from the traditional healers and house wives in the study area, the ailments were categorized into 5 and 3 other categories (Table 1) viz. Genito urinary ailments (GUA), Dermatological infections/disorders (DID), Gastro intestinal ailments (GIA), Kidney stone (KS), Poisonous bites (PB), Food products (FP), Spice (SP) and Others (OT).

Table 1:- Ailments and other categories

\begin{tabular}{|c|c|c|}
\hline S/N & Ailment categories & Biomedical terms/Use \\
\hline 1 & Genito urinary ailments (GUA) & Menstrual problems, postnatal care \\
\hline 2 & Dermatological infections/disorders (DID) & Pimple, skin irritation, burning injury \\
\hline 3 & Gastro intestinal ailments (GIA) & Stomach pain \\
\hline 4 & Poisonous bites (PB) & Spider poison, snake bite \\
\hline 5 & Kidney stone (KS) & Kidney stone \\
\hline 6 & Spice (SP) & Spices \\
\hline 7 & Food products (FP) & Pood, baby food, body immunization. \\
\hline 8 & Others (OT) cleaning, food serving, etc \\
\hline
\end{tabular}

Data Analysis:-

Informant consensus factor (Fic)

The informant consensus factor (Fic) was used to find out if there was an agreement in the use of Zingiberales in the ailment categories between the plant users in the study area. The Fic was calculated by the following formula (Heinrich, 1998) (Eq. 1).

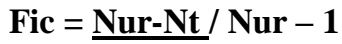

Where Nur refers to the number of use-reports for a particular ailment category and Nt refers to the number of taxa used for a particular ailment category by all informants. The product of this factor ranges from 0 to 1 . A high value (close to 1.0) indicates that relatively few taxa are used by a large proportion of the informants. A low value indicates that the informants disagree on the taxa to be used in the treatment within a category of illness.

Use value (UV):-

The relative importance of each plant species known locally to be used as herbal remedy is reported as the use value (UV) and it was calculated using the following formula Phillips et al., 1994) (Eq. 2).

$\mathbf{U V}=\Sigma \boldsymbol{U} / \mathbf{N}:-$

$\sum \mathrm{U} n$ where $\mathrm{UV}$ is the use value of a species, $\mathrm{U}$ is the number of use reports cited by each informant for a given plant species and $\mathrm{n}$ is the total number of informants interviewed for a given plant.

\section{Result and Discussion:-}

Documentation of Ethnobotanical Knowledge:-

The ethnobotanical studies on Zingiberales used by Mavilan and Malavettuvan tribe distributed in different area of of Kasaragod District were carried (Plate 1). A total of 11 ethnobotanically important plant species distributed in 5 families such as Zingiberaceae, Marantaceae, Costaceae, Canaceae and Musaceae were recorded. The taxa under study are Curcuma longa, C. zeodaria, Elatteria cardamoum, Hedychium spicatum, H. coronarium, Zingiber officinale, Z. zerumbet, Maranta arundinacea, Canna edulis, Costus speciosus and Enseta superbum. The details are given in the Table 2. 
Table 2:- Ethnobotanical uses of Zingiberales (MV=Malavettuvan, ML= Mavilan).

\begin{tabular}{|c|c|c|c|c|}
\hline $\begin{array}{l}\mathrm{S} / \\
\mathrm{N}\end{array}$ & Binominal Name \& Family & Parts used & $\begin{array}{l}\text { Diseases/ } \\
\text { Others }\end{array}$ & Mode of Administration \\
\hline 1 & $\begin{array}{l}\text { Zingiber officinale Roscoe } \\
\text { (Zingiberaceae) }\end{array}$ & Rhizome & $\begin{array}{l}\text { Gas } \\
\text { trouble, } \\
\text { digestive } \\
\text { problems, } \\
\text { spice }\end{array}$ & $\begin{array}{l}\text { For gas trouble and digestive problems, the } \\
\text { juice extracted from the fresh rhizome is } \\
\text { taken internally and also as a spice (MV). } \\
\text { Fresh rhizome along with salt is taken } \\
\text { internally for gas trouble. Fresh rhizome is } \\
\text { used as an ingredient for the preparation of } \\
\text { medicine for snake bite (ML). }\end{array}$ \\
\hline 2 & $\begin{array}{l}\text { Zingiber zerumbet (L.) Roscoe ex } \\
\text { Sm } \\
\text { (Zingiberaceae }\end{array}$ & $\begin{array}{l}\text { Inflorescen } \\
\text { ce }\end{array}$ & $\begin{array}{l}\text { Agricultura } \\
1 \text { use }\end{array}$ & $\begin{array}{l}\text { The juice extracted from the inflorescence } \\
\text { is applied to paddy for wilting of disease in } \\
\text { Paddy (Nellu chuvadu pazhuppu (MV). }\end{array}$ \\
\hline 3 & Curcuma longa L. (Zingiberaceae) & Rhizome & Snake bite & $\begin{array}{l}\text { Small pieces of fresh rhizomes are used to } \\
\text { remove the parts of snake teeth from the } \\
\text { wound and also as a spice (MV, ML). }\end{array}$ \\
\hline 4 & $\begin{array}{l}\text { Curcuma zeodaria Roscoe } \\
\text { (Zingiberaceae) }\end{array}$ & Rhizome & $\begin{array}{l}\text { Baby food, } \\
\text { constipatio } \\
\text { n }\end{array}$ & $\begin{array}{l}\text { Powder prepared from rhizomes is used for } \\
\text { preparation of food items (MV). Fresh } \\
\text { rhizomes are eaten for abdominal problems } \\
\text { (ML). }\end{array}$ \\
\hline 5 & $\begin{array}{l}\text { Hedychium spicatum } \mathrm{Sm} . \\
\text { (Zingiberaceae) }\end{array}$ & Fruits & $\begin{array}{l}\text { Skin } \\
\text { diseases, } \\
\text { (Vatta } \\
\text { chori) }\end{array}$ & $\begin{array}{l}\text { For the treatment of 'vatta chori,' the fruit } \\
\text { is crushed with water and the paste is } \\
\text { applied on diseased area (MV). }\end{array}$ \\
\hline 6 & $\begin{array}{l}\text { Hedychium coronarium Koenig. } \\
\text { (Zingiberaceae) }\end{array}$ & Flowers & $\begin{array}{l}\text { For pooja, } \\
\text { garland } \\
\text { making }\end{array}$ & $\begin{array}{l}\text { Tribal's used flowers for worship and } \\
\text { preparation of Garlands (MV, ML). }\end{array}$ \\
\hline 7 & $\begin{array}{l}\text { Eletteria cardamomum (L.) Maton } \\
\text { (Zingiberaceae) }\end{array}$ & Seeds & $\begin{array}{l}\text { Digestive } \\
\text { problem, } \\
\text { abdominal } \\
\text { pain }\end{array}$ & $\begin{array}{l}\text { For curing digestive problem, the dried } \\
\text { seeds are powdered and mixed with milk } \\
\text { and taken internally and also as a spice } \\
\text { (MV, ML). }\end{array}$ \\
\hline 8 & Ensete superbum Roxb.(Musaceae) & Seeds & $\begin{array}{l}\text { Kidney } \\
\text { stone }\end{array}$ & $\begin{array}{l}\text { The powder prepared from the seeds are } \\
\text { mixed with coconut water or water and } \\
\text { taken internally (MV, ML). }\end{array}$ \\
\hline 9 & $\begin{array}{l}\text { Canna edulis Gawl. } \\
\text { (Cannaceae }\end{array}$ & Rhizome & Food & The fresh rhizomes are edible (MV, ML). \\
\hline 10 & $\begin{array}{l}\text { Costus speciosus J. Koening } \\
\text { (Costaceae) }\end{array}$ & Rhizome & $\begin{array}{l}\text { Stomach } \\
\text { pain }\end{array}$ & $\begin{array}{l}\text { The Juice extracted from the fresh rhizome } \\
\text { is for stomach pain (MV). }\end{array}$ \\
\hline 11 & $\begin{array}{l}\text { Maranta arundinacea } \mathrm{L} . \\
\text { (Marantaceae) }\end{array}$ & Rhizome & Food & $\begin{array}{l}\text { The fresh rhizome is edible (MV). } \\
\text { Fresh rhizome eaten for menstrual diseases } \\
\text { (ML). }\end{array}$ \\
\hline
\end{tabular}

Informant consensus factor:-

The product of Fic ranges from 0 to 1. A high value Fic indicates the agreement of selection of taxa between informants, whereas a low value indicates disagreement (Ragupathy et al., 2008). The Fic values in the present study ranged from 0.69 to 1 (Fig 1 \& Table 3 ). The highest Fic was reported for Genito urinary ailments (GUA) (1.0) and lowest for Gastro intestinal ailments (GIA) (0.69). 
Table 3:- Informant consensus factor (Fic) of Zingiberaceous plants by Malavettuvan \& Mavilan Tribals.

\begin{tabular}{|c|c|c|c|c|}
\hline S/No & Ailment category/Food/Spice & No. of use report & No of Taxa & Fic \\
\hline 1 & $\begin{array}{c}\text { Dermatological } \\
\text { infections/disorders(DID) }\end{array}$ & 9 & 3 & 0.75 \\
\hline 2 & Genito urinary ailments (GUA) & 7 & 1 & 1 \\
\hline 3 & Gastro intestinal ailments(GIA) & 14 & 5 & 0.69 \\
\hline 4 & Kidney stone(KS) & 5 & 2 & 0.75 \\
\hline 5 & Poisonous bites(PB) & 9 & 3 & 0.88 \\
\hline 6 & Food products(FP) & 8 & 3 & 0.71 \\
\hline 7 & Spice(SP) & 7 & 2 & 0.83 \\
\hline
\end{tabular}

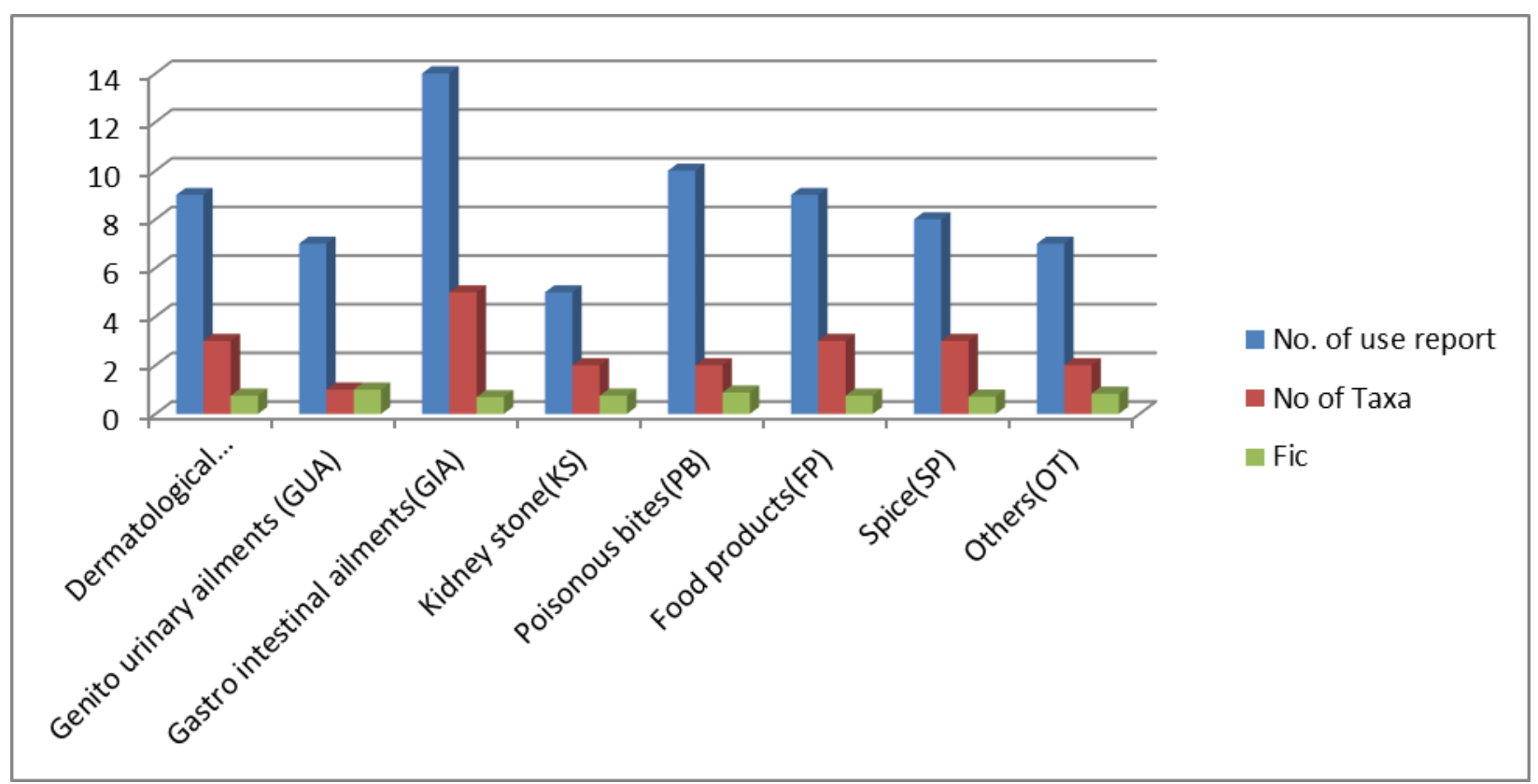

Use values:-

Fig 1:- Informant consensus factor (Fic)

The most commonly used species are Maranta arundinacea, Zingiber officinale, $C$. zeodaria Curcuma longa, etc. The use value ranges from 1.5 to 2.6 (Figure $2 \&$ Table 4 ).

Table 4:- Use value (UV) of Zingiberaceous plants by Malavettuvan \& Mavilan Tribals

\begin{tabular}{|c|c|c|c|c|}
\hline S/N & Binomial name & $\begin{array}{c}\text { No. of use } \\
\text { reports(U) }\end{array}$ & $\begin{array}{c}\text { Total no. of } \\
\text { informants(N) }\end{array}$ & Use value(UV) \\
\hline 1 & Zingiber officinale & 7 & 3 & 2.33 \\
\hline 2 & Zingiber zerumbet & 2 & 1 & 2 \\
\hline 3 & Curcuma longa & 15 & 7 & 2.14 \\
\hline 4 & Curcuma zedoria & 7 & 3 & 2.33 \\
\hline 5 & Hedychium spicatum & 2 & 1 & 2 \\
\hline 6 & Hedychium coronorium & 6 & 3 & 2 \\
\hline 7 & Elatteria cardamomum & 2 & 4 & 1.75 \\
\hline 8 & Enseta superbum & 7 & 4 & 1.5 \\
\hline 9 & Canna edulis & 6 & 1 & 2 \\
\hline 10 & Costus speciosus & 2 & 5 & 2.6 \\
\hline 11 & Maranta arundinaceae & 13 & & \\
\hline
\end{tabular}




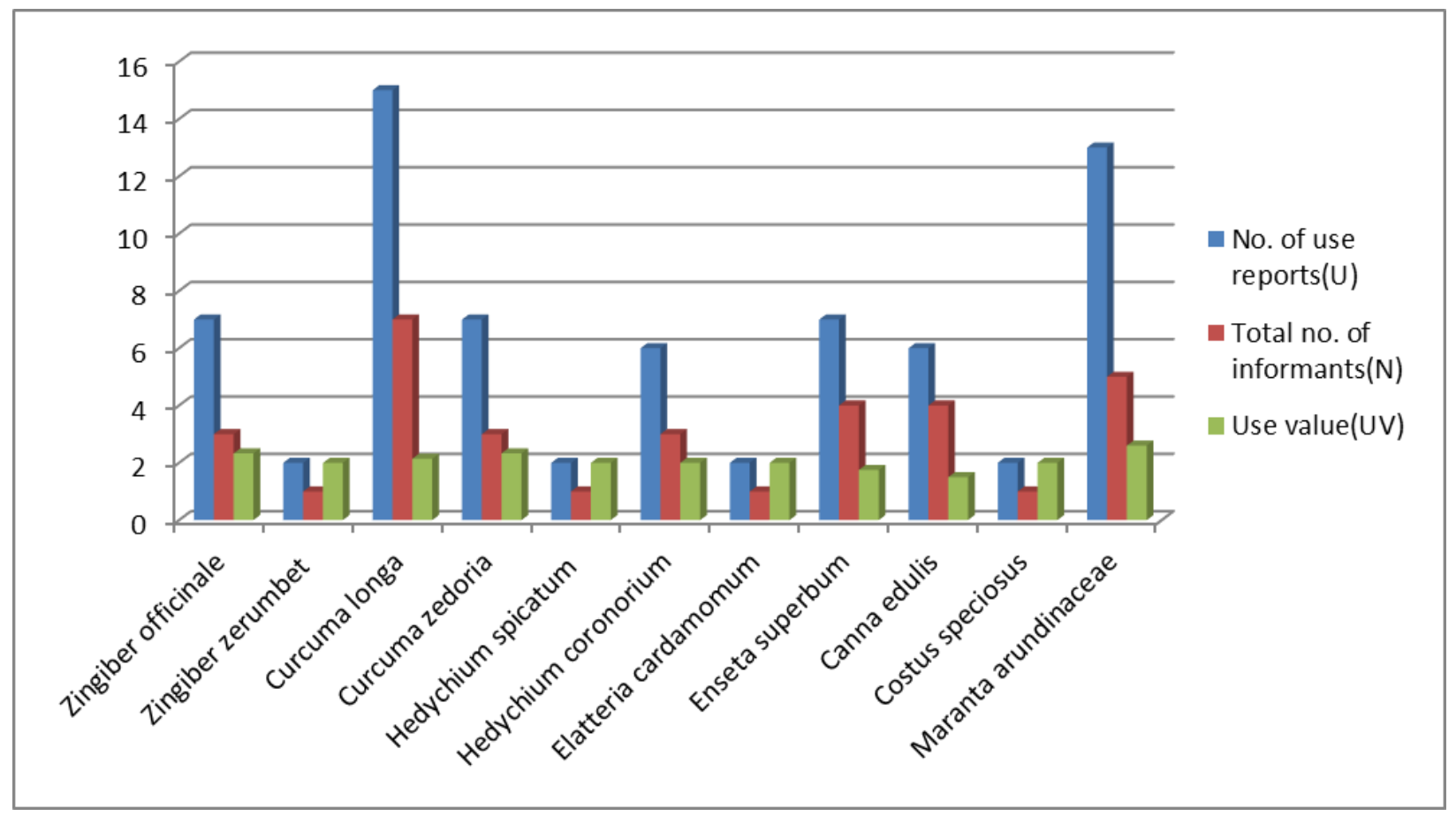

Fig 2:- Use value (UV) of Zingiberaceous plants.

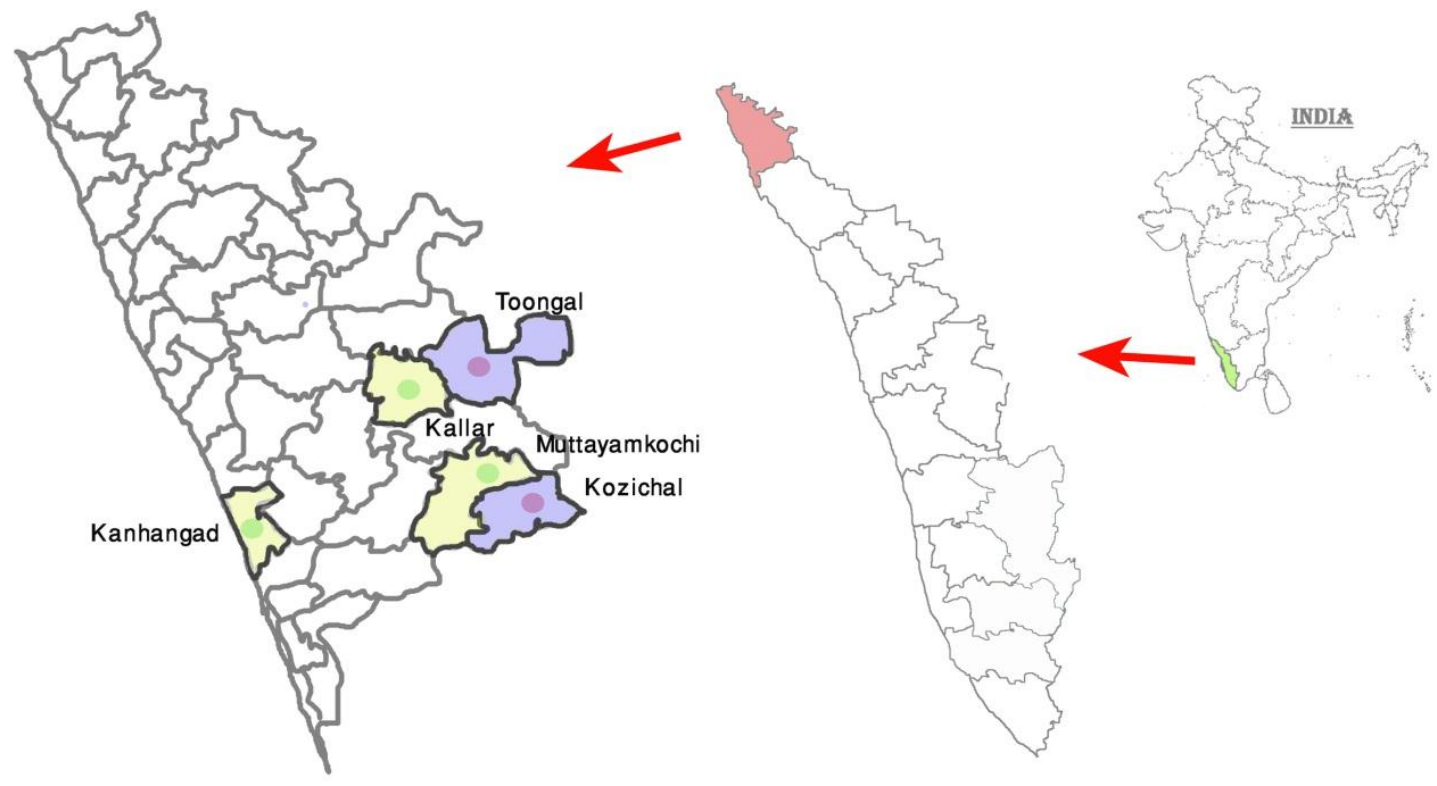

Map 1. Kasaragod District of Kerala 

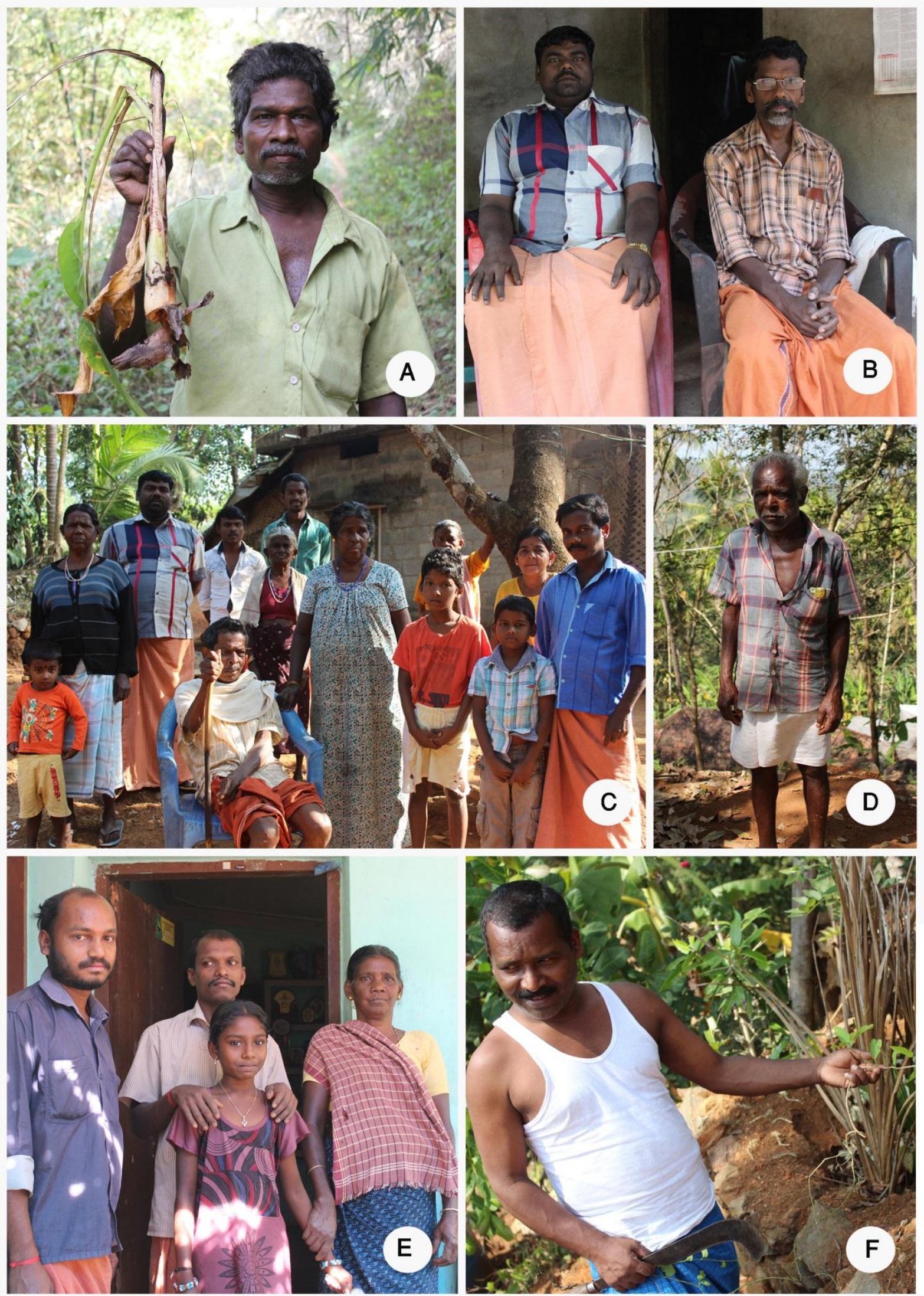

Plate 1. A-C: Members of Malavettuvan Tribe. D-F: Members of Mavilan Tribe. 


\section{Conclusion:-}

The tribal people of Kasaragod District cultivate many plants in their home gardens and premises for food, medicine, spice, etc. It is observed that some plants were used for ailment like kidney and urinary disorder, skin related diseases, etc. The study have shown that Zingiberales are effective in Ayurvedic and other system of medicine. Zingiberales are well-known for its medicinal and economic significances. Many species are used as sources of indigenous medicines, food, spices, condiments and ornamentals. The traditional knowledge explored in this study significantly contributes for the wellbeing of mankind with locally available natural resources.

\section{Acknowledgements:-}

The authors are grateful to Kerala State Council for Science, Technology and Environment (KSCSTE) for the financial assistance to the research project on Ethnobotanical studies on Zingiberaceae of Kerala (029/SRSLS/2014/CSTE). Thanks are due to the Department of Forests, Kerala State for providing necessary forest permission.

\section{References:-}

1. Chaudhary, K., Singh, M. and Pillai, U. (2008): Ethanobotanical survey of Rajasthan- an update. Ame. Eura. J. Bot., 1(2): 38-45.

2. Heinrich, M., Ankli, A., Frei, B., Weimann, C. and Sticher, O. (1998): Medicinal plants in Mexico: healers consensus and cultural importance. Soc. Sci. Med., 47: 91-112.

3. Kong, J.J., Xia, Y.M. and Li, Q.J. (2010): Inflorescence and flower development in Hedychieae (Zingiberaceae): Hedychium coccineum Smith. Protoplas., 247: 83-90.

4. Kress, W.J., Prince, L.M. and Williams, K.J. (2002): The Phylogeny and new classification of the gingers Zingiberaceae, Evidence from molecular data. Amer. J. Bot. 89(11): 1682-1696.

5. Phillips, O., Gentry, A.H., Reynel, C., Wilkin, P. and Galvez-Durand, B.C. (1994): Quantitative ethnobotany and Amazonian conservation. Conserv. Biol., 8: 225-248.

6. Ragupathy, S., Steven, N.G., Maruthakkutti, M., Velusamy, B. and Ul-Huda, M.M. (2008): Consensus of the 'Malasars' traditional aboriginal knowledge of medicinal plants in the Velliangiri holy hills, India. J. Ethnobiol. Ethnomed., 4: 8.

7. Report on the socio economic status (RSES). (2013): Scheduled tribe's development department government of Kerala.

8. Tomlinson, P.B. (1969): Commelinales - Zingiberales. In: Metcalfe CR. Anatomy of the monocotyledons. Clarendon Press, Oxford, pp. 341-359. 